\title{
NÜKLEER TERÖRİM VE TEHDİT BOYUTLARINA YÖNELİK ÇIKARIMLAR
}

\author{
NUCLEAR TERRORISM and INFERENCES ABOUT ITS THREAT \\ DIMENSIONS
}

Yrd. Doç. Dr. Saadet Demirci, Çankırı Karatekin Üniversitesi, İktisadi ve İdari Bilimler Fakültesi, Uluslararası İlişkiler Bölümü, sadatdemirci@karatekin.edu.tr

\begin{abstract}
ÖZET
$\mathrm{Bu}$ çalışmada, nükleer terörizm kavramı değerlendirilmekte ve nükleer terörizm tehdidinin boyutları analiz edilmektedir. Nükleer terörizm tehdidi tüm dünyayı endişelendiren bir konudur ve gerekli tedbirler alınmadığı sürece sonuçları tahmin edilemez facialara yol açabilecek bir tehdit unsurudur. Nükleer terörizmin bu yüzden ciddi bir şekilde araştırılması ve tehdit boyutlarının açıklanması gerekmektedir.

$\mathrm{Bu}$ nedenle çalışmada kitle imha silahlarının hangi yollarla elde edildiği, tehdit ölçüleri ve teröristlerin nükleer silah yapma ihtimalleri incelenmektedir.

Bu konuda sadece uzmanların değil tüm sivil vatandaşların da bilinçlendirilmesi ve nükleer silah yapımına karşı yürütülen mücadeleye katılması sağlanmalıdır. Bu konuda medyaya büyük bir görev düşmektedir. Medyanın vatandaşları nükleer terörizm hakkında bilinçlendiren yazı ve makaleler yayımlayarak tehdit boyutlarını açıklaması birçok açıdan önemlidir. Vatandaşları bilinçlendirerek birçok konuda destek alınabilir: Örneğin internette kitle imha silahları yapımı hakkında bilgiler içeren web sitelerin ihbar edilmesi ve kapatılmasının sağlanması teşvik edilebilir.

Bir diğer önemli konu nükleer silah yapımı için kullanılan materyallerin çalınmasıdır. Teröristlerin birçok kez kendi imkânlarıyla nükleer silah yapmaya çalıştıkları ve bu tür silahların basit materyaller ile yapılmasının mümkün olduğu bilinmektedir. Bunun için bu konularda yayımlanan kaynaklardan anlayabilen bir uzmanın yardımı yeterlidir. Bunu önleyebilmek için nükleer tesislerin ve bu tür silah yapımı için kullanılabilecek materyallerin ciddi bir şekilde teröristlerden korunması gerekmektedir. Bu çalışmada bunun için yürütülen tedbirler ele alınmakta ve bunların ne kadar etkili olduğu konusunda değerlendirmeler yapılmaktadır.

Anahtar Sözcükler: Nükleer Terörizm, Kitle İmha Silahları, Kimyasal Silahlar, Biyolojik Silahlar

\section{IMPLICATIONS ABOUT NUCLEAR TERRORISM AND DIMENSION OF THREAT}

ABSTRACT

In this article, the concept of 'nuclear terrorism' is evaluated and the dimension of nuclear terrorism threat is analyzed. Nuclear terrorism threat is an issue, that is worried all globe. Without any prevention of nuclear terrorism, results of nuclear terrorism are a disaster; its dimension cannot be estimated and measured. Therefore, it is necessary to search and explain threat dimension of nuclear terrorism seriously.
\end{abstract}


Consequently, how terrorists hold mass destruction weapons, threat measures of nuclear terrorism and possibilities of terrorists' making nuclear weapons are explicated in this article.

Not only experts, also ordinary citizens should be made conscious of nuclear terrorism and should participate combating against making nuclear weapons. The mass media should play the main role in this point. One of the most important duties of mass media related to this issue is to publish articles, which make conscious citizens of nuclear terror and explain dimension of threat. By this way, an important support can be received. Citizens can report some web sites, which consist of information about making mass destruction weapons, and can provide to be closed these web sites.

Another important issue is pilferage of some materials, which is used to make nuclear weapons. Terrorists attempt to make nuclear weapons themselves and it is possible to make some nuclear weapons by basic materials and methods are well known. To make a nuclear weapon, it is enough to an expert's contribution. It is necessary to safeguard of nuclear buildings and materials against terrorists, seriously. These kinds of measures are undertaken and the answer, which how much it is effective, is evaluated in this article.

Key words: Nuclear terrorism, mass destruction weapons, chemical weapons, biological weapons.

\section{GİRİ̧̧}

Nükleer silahların icadı, yaygınlaşması ve bazı devletlerin bu tür silahları bulundurması sonucu uluslararası toplum ciddi tehlikelerle karşı karşıya kalmıştır. Karşı karşıya kalınan bu fenomenin adı nükleer terörizmdir. Nükleer terörizm ile terörü amaçlarına ulaşmak için güçlü bir araç olarak gören çeşitli terör örgütlerinin faaliyetlerinin genişlemesi arasında ciddi bir bağlantı vardır. Otuzdan fazla ülkede yaklaşık 450'si sanayi ve 100 'den fazlası bilimsel amaçlı olmak üzere kurulan reaktör, 10.000 'den fazla kitle imha silahı bulunmaktadır. $\mathrm{Bu}$ durum da terör örgütlerinin faaliyetlerini genişletmeleri, dünyanın en hassas bölgelerinde terör saldırıları gerçekleştirebilmeleri için iyi bir imkân yaratmaktadır. Bu alan içinde yüz binlerce uzmanın yer alması ve bu uzmanlar arasında terörizmi destekleyebilecek insanların da bulunması ihtimali durumun ciddiyetini daha da arttırmaktadır. Bu şartlarda toplumu ciddi facialara yol açabilecek terörist saldırılardan korumak çok daha zorlaşmaktadır.

Nükleer terörizm, terörist saldırıların en tehlikeli ve en çok zarar verebilecek şeklidir; birçok farklı türde ortaya çıkabilir. Bunlardan en tehlikelisi nükleer silahların çalınarak kullanılabilmesi tehdididir. Kitle imha silahlarının yapımı için kullanılan nükleer atıkların ve diğer materyallerin çalınması veya yasa dışı yollardan elde edilmesi de benzer bir tehdittir. Bilimsel amaçlı kurulan nükleer tesislere yönelik saldırılar ise büyük alanlara, su kaynaklarına radyasyon yayılmasına ve insan hayatını tehlikeye atabilecek daha ciddi birçok felakete yol açabilir.

Dünya nüfusunun çoğunluğu dünyanın çeşitli yerlerinde gerçekleşebilecek nükleer terörizm saldırılarının doğurabileceği sonuçlar hakkında çok az bilgiye sahiptir ve bu yüzden de bu insanlar bu tür saldırıların boyutunun ciddiyeti hakkında tahmin yürütememektedirler. İstatistiklere bakıldığında veriler bu tehlikeye karşı hassasiyetin arttırılması gerektiğini göstermektedir. Sadece son 20 y1l içerisinde Avrupa'da ve 
Amerika'da nükleer tehlikenin artmasına sebep olabilecek 150'den fazla olayın gerçekleştiği bildirilmektedir. Bunlar arasında nükleer tesislere yakın bölgelere yönelik saldırılar, bu tesislere sızma teşebbüsleri, nükleer uzmanlarına yönelik saldırılar ve kaçırma olayları, nükleer atıkların ve kitle imha silahlarının yapımı için gereken diğer materyallerin çalınması yer almaktadır. Bu tür faaliyetler birçok farklı yönde gerçekleşebilmektedir ve bu faaliyetlerin doğurabileceği sonuçları tahmin edebilmek mümkün görünmemektedir; fakat bu sonuçların tehlike boyutları hiçbir zaman küçümsenmemelidir.

Nükleer terörizm, şu ana kadar sosyal, siyasi, ekonomik, dini, teknik ve askeri yönlerden yeteri kadar araştırılmamıştır. Bu yüzden sorunun çözümü için çok yönlü bir girişimde bulunulması gerekmektedir. Bunun için tüm dünya liderlerinin bir araya gelmesi, bütün uluslararası camianın tabi olmasını zorunlu kılacak uluslararası yasaların hazırlanması ve nükleer terörizmi ortadan kaldırmak için etkili bir sistem geliştirilmesi gerekli görünmektedir. Çünkü bu sorun ancak bütün uluslararası toplumun ve uluslararası örgütlerin bir arada hareket etmesiyle çözülebilecektir.

Günümüzde nükleer terörizm konusunun gündemden düşürülmemesinin ve derinlemesine incelenmesinin gerekliliği kadar bu tehlikeyi ortadan kaldırabilecek yöntemlerin araştırılması da şarttır. Bu amaçlara hizmet olarak çalışmada nükleer terörün çeşitli yönleri incelenerek tehdit boyutları ortaya konmaktadır.

\section{NÜKLEER TERÖRIZM KAVRAMI}

Soğuk Savaş öncesi terörizmin genel tanımı "bir kişiyi öldürüp milyonları korkutmak için yapılan sembolik bir eylem" şeklinde yapılmaktaydı (Thorton, 1964, s.73). 11 Eylül 2001'de ABD'ye yapılan terörist saldırılardan sonra "kurallar" değişti ve yapılan terörist eylemlerin karakteri insanların toplu şekilde öldürülmesi yönünde gelişmeye başladı. Teröristlerin, eylemleri için kitle imha silahları kullanma tehdidinde bulunmaları ya da nükleer terörizmin ortaya çıkması bunun en büyük nedenlerindendir.

Nükleer terörizm, kişilerin veya terörist örgütlerin siyasi ve/veya ekonomik amaçları uğruna nükleer ve kimyasal silahları insanları toplu şekilde öldürmek, ekolojik zarar vermek, psikolojik etkileşim yaratmak için kullanması veya kullanma tehdidi içeren eylemleri gerçekleştirmesidir (http://usinfo.state.gov/journals/itps/0305/ijpr/cameron.html, Mart 2005).

Nükleer terörizm, teröristlere çok önemli avantajlar sağlamaktadır. Bunun en büyük nedeni nükleer silahların çok sayıda insana zarar verebilmesi ve medyanın ilgisini geniş çapta çekebilmesidir. Ayrıca bir terörist örgütün nükleer silah kullanma tehdidinin ne ölçüde gerçek olduğunu anlamak oldukça zordur. Dolayısıyla bu durum, nükleer tehdit altındaki bir ülkenin terörist şantajlara maruz kalması sonucunu doğurabilir.

1990’lı yıllarda nükleer terörizm tehdidinin ortaya çıkmasının nedenleri şu şekilde gelişmiştir: İlk olarak, Sovyetler Birliği'nin yıkılmasının ardından kitle imha silahlarının bütün türleri üzerindeki kontrol azalmıştır. İkinci olarak, enformasyon teknolojisinin gelişmesiyle birlikte insanların internetten kitle imha silahlarının yapımı için bilimsel ve teknolojik bütün bilgilere ulaşımı kolaylaşmıştır (http://www.zerkalo-nedeli.com/nn/show/371/3309, 7.01.2001). 
1995 yılında Aum Shinriki (Adalet Kurulu/Yüce Gerçek) terörist örgütü tarafından Tokyo metrosunda kimyasal madde "sarin" kullanılması, teröristlerin kitle imha silahlarına ulaşmasının ve eylemler için kullanmasının mümkün olduğunun ilk örneği olmuştur.

Nükleer enerjinin gelişmesi, kitle imha silahlarına ulaşım kolaylığını ciddi bir şekilde etkilemektedir. Günümüzde 30'dan fazla ülkede 440 sanayi ve 280 araştırma reaktörü çalıştırılmaktadır. Sadece bin megabaytlık bir reaktör, bir y1l içerisinde $40-50$ atom bombası yapılacak kadar platon üretebilmektedir (Belous, 2004).

Devletler için en büyük tehlikelerden biri, nükleer silahların teröristler tarafından çalınması ve terörist eylemlerde kullanılma tehdidi içermesidir. Nükleer silah üretiminde kullanılan maddelerin teröristlerin eline geçmesi de aynı tehlikeleri içermektedir. Radyoaktif maddelerin teröristler tarafindan kullanılması, tehdidin ciddiyetini gelişen örneklerle doğrulamaktadır. Tıp, sanayi, kontrol ve ölçü aparatlarında geniş bir şekilde kullanılan radyoaktif kaynakların kontrollerinin yapılmaması, bu tür maddelerin binlercesinin kaybına yol açmıştır ve terörist örgütlerin bunları edinmesi kolaylaşmıştır (http://nvo.ng.ru/concepts/2004-10-08/4_terrorism.html, 8.10.2004).

Nükleer silah kullanılarak yapılan eylemlerin bir örneği $23 \mathrm{Kasım}$ 1995'te Rusya'da gerçekleşmiştir. Teröristler, Moskova İzmaylovskiy Parkı'na radyoaktif izotop 137 ve dinamit içeren atom bombası yerleştirerek şehri bombalamayı planlamıştır. Bomba, eylemciler tarafından patlatılmadan son anda yerli televizyon kanalına bildirilmiştir. $\mathrm{Bu}$ da, Rusya'daki Çeçen teröristlerin nükleer silahlara ulaşabildiklerinin ve onları eylemlerinde kullanabileceklerinin bir göstergesi olarak değerlendirilmiştir (Saradzyan, 2003). SSCB'nin dağılması, uluslararası nükleer güvenlik için korkunç bir tehlike yaratmıştır; çünkü Sovyetler'e ait bütün kitle imha silahları bağımsızlıklarını kazanan dört ülke arasında dağıtılmıştır. Kitle imha silahlarının Kazakistan, Beyaz Rusya ve Ukrayna'dan Rusya'ya getirilmesi için siyasi ve ekonomik kaos içinde ciddi bir diplomatik gayret gösterilmiştir. Rusya Güvenlik Bakanlığı tarafından 2 bin nükleer bombanın Rusya'ya götürüldüğü bilinmektedir; fakat bütün kitle imha silahlarının koruma altına alındığına ve güvenli bir şekilde getirildiğine dair bir garanti bulunmamaktadır. 1991 yılında ABD Güvenlik Bakanı Dick Cheney, "Meet the Press" Gazetesi'ne verdiği mülakatta Sovyetler'in nükleer silahlarına \% 99 kontrol garantisi vermesi durumda bile 250 nükleer silahın kontrolsüz kaldığını belirtmiştir (http://www.globalaffairs.ru/articles/0/3069.html, 18.02.2004).

Teröristlerin eylemlerinde kitle imha silahı kullanma tehdidi bugün de ciddiyetini korumaktadır. ABD'nin "kara listesinde" yer alan 33 uluslararası terörist örgütün çoğu nükleer silah üretimi için kullanılan maddelere ilgi duymaktadır (http://info.trud.ru/shortnews.php?id=18782, 2003).

El Kaide terör örgütü lideri Usame Bin Laden, 1998 yılında kitle imha silahlarının elde edilmesini bir "dini görev" şeklinde belirtmiştir. Afganistan'da El Kaide tarafından desteklenen eğitim kamplarında terörist örgüt üyelerine internetten, bilimsel ve teknolojik kaynaklardan, konferanslardan kimyasal, biyolojik, nükleer ve radyolojik silahlarla ilgili bilgiler verilmektedir (http://npc.sarov.ru/digest/142004/appendix3p1.html, 30.05.2003).

Ayrıca El Kaide'nin tehlikeli kimyasal madde ve toksinler elde etmek için girişimlerde bulunduğu da bilinmektedir. El Kaide'nin 
Afganistan'daki "bürosunda" bulunan belgelerden Bin Laden'in nükleer silah üretimi için sanılandan daha ciddi projeleri olduğu belirlenmiştir (http://npc.sarov.ru/digest/42001/section5.html, 1.10.2001). Bin Laden ve El Kaide örgüt üyeleri tarafından birçok kez nükleer silah üretiminde kullanılan maddelere ulaşma çabaları gösterilmiştir; fakat fiili olarak bu maddelere ulaştıklarına dair bir bilgi mevcut değildir.

Rusya istihbarat servisi, 1998 yılında Bin Laden'in yönettiği Pakistanlı terörist örgüte nükleer silah üretiminde kullanılan, belirlenemeyen miktarda uranyum satmaya çalışan bir grup teröristin yakalandığını bildirmiştir.

Uzmanların görüşlerine göre, El Kaide terör örgütü hâlâ nükleer madde arayışındadır. ABD istihbarat servisi, Laden'in nükleer bomba yapımı için kullanılan yüksek seviyede radyoaktif maddeleri elde etmesinden kuşkulandığını belirtmiştir. $\mathrm{Bu}$ maddelerin atom bombası yapımından ziyade atmosferin kirletilmesi için kullanılacağ düşünülmektedir.

Harvard Üniversitesi’nin nükleer silahlar uzmanı M. Bann, Bin Laden ağının çok iyi bir şekilde organize edildiğini ve nükleer kaynaklara ulaşabileceği konusunda hiç şüphe duymadığını belirtmiștir (http://npc.sarov.ru/digest/32001/section1p1.html,19.09.2001).

İsrail ve Rusya'dan gelen raporlara göre Bin Laden'in eski Sovyet nükleer kaynaklarına ve silahlarına ulaşmak için Çeçen teröristlerle işbirliğinde bulunduğuna dair belgeler bulunmaktadır (http://www.globalaffairs.ru/articles/0/3069.html, 17.09.2001).

St. Petersburg Times Gazetesi, ABD yönetiminin verdiği bilgileri aktararak Amerikan istihbarat servislerinin kanıtlarına göre Bin Laden'in Afganistan'da nükleer silah üretimi için kurulan gizli laboratuarı olduğunu belirtmiştir. Fakat Bin Laden'in fiili olarak kimyasal, biyolojik veya nükleer silah ürettiğine dair bir kanıt yoktur (http://npc.sarov.ru/digest/32001/section1p1.html, 19.09.2001).

New York Daily News Gazetesi, 1996 yılında para transfer etmeye çalıșırken yakalanan ve daha sonra El Kaide örgütünden ayrılan Jamal Al Fadl'ın ifadelerine dayanarak El Kaide örgütünün tek tutuklu üyesi Mamdu Mahmut Salim'in, 1993 y1lında Bin Laden'in nükleer silah elde etme çalışmalarında yer aldığını yazmıştır. Al Fadl'ın yüksek zenginleştirilmiş uranyum satın almak için Sudan yönetimi ile görüştüğü ve 1,5 milyon dolar karşılığında alınan maddenin kendisi tarafından MM Salim'e verildiği açıklanmıştır (http://npc.sarov.ru/digest/32001/section1p1.html, 19.09.2001). Bu tür haberler, teröristlerin nükleer silah üretimi konusunda ne derece başarılı olabilecekleri sorusunu gündeme getirmektedir.

1997 y1lında Kevin O’Nil tarafindan hazırlanan ve daha sonra web sayfasında yayımlanan raporda, teröristlerin nükleer içeren veya radyasyon saçan bir silah üretip üretemeyecekleri konusu ile ilgili detaylı araştırmalar yapılmıștır. Rapordan çıkarılan sonuca bakılırsa teröristlerin nükleer silah üretimi için gerekli bütün maddeleri elde etmesi çok zordur. Buna rağmen terörist örgütlerin bu olanaklara nükleer kaynakları çalma yöntemiyle zamanla ulaşabileceği ihtimali yüksektir. Fakat terörist örgütlerin, kaynaklardan nükleer silah üretebilme kapasitelerini değerlendirmek oldukça zordur. 
Herhangi bir devletin fiili desteği olmadan iyi organize ve finanse edilen terörist grupların kaynaklardan nükleer silah üretebilmek için gerekli uzmanlığa ve tesisata sahip olabilmeleri mümkündür (http://npc.sarov.ru/digest/42001/section5.html, 19.09.2001).

1970'li y1llarda, Güney Afrika'da nükleer silah üretimi için başlangıçta istihbarat servislerinin tespit etmesinin zor olduğu basit makineler kullanıldığı gibi teröristler de silah üretimi için küçük bir tesisat kullanabilirler. Terörist örgütlere silah yapımı için Güney Afrika'da kullanılan tesisatın yarısı yeterli olabilecektir. Teröristlerin bu silahları eylemlerinde kullanıp kullanmayacaklarına cevap vermek biraz daha zordur. Önceki yıllarda uzmanlar nükleer terörizmin ortaya çıkmasının imkânsız olduğunu söylemişlerdir; fakat yaşadığımız dönemde de bunu iddia etmek mümkün görünmemektedir.

Bugünün teröristleri siyasi amaçla değil, dini motiflerle hareket etmektedirler ve hedefleri olabildiğince fazla insanı öldürmektir. Bu yüzden ellerine nükleer silah geçtiği zaman kullanacaklarından şüphe duyulmamalıdır. Bugüne kadar terörist eylemlerde nükleer silah kullanılmaması, terörist örgütlerin önündeki ciddi siyasi engellerle açıklanabilirdi. 1990 yılında CIA, terörist örgütlerin eylemlerinde nükleer silah kullanmak konusundaki tedirginliklerinin "sponsor" kaybetme korkusundan dolayı süreceği sonucuna varmıştı (http://npc.sarov.ru/digest/42001/section5.html, 19.09.2001).

\section{NÜKLEER TERÖRİZMİN TEHDİT ÖLÇÜLERİNIN ANALİZI}

Nükleer silahlar büyük çapta yıkıcı güce sahip olan savaş araçlarıdır, kısa süre içerisinde geniş kitleye ulaşımı ve yok edici özellikleriyle terör örgütlerin ulaşmaya çalıştıkları en tehlikeli silahtır.

Terörist eylemlerde nükleer silah veya radyoaktif madde kullanma tehdidi boyutları nükleer maddelerin, nükleer silahların ve nükleer atıkların çalınmalarıyla ilintili olarak değerlendirilmektedir. Büyük felaketlere yol açacak bu faciayı önlemek için teröristlerin bu tür silahlara ulaşmasına yol açabilecek tüm ihtimaller gözden geçirilmeli ve risk ölçüleri analiz edilmelidir.

\section{Nükleer Maddelerin Çalınması}

Nükleer hırsızlık olayları ile ilgili ilk örnekler 1994 yılında Çek Cumhuriyeti'nin bir nükleer güç istasyonundan $3 \mathrm{~kg}$. ve 1997 yılında Litvanya'dan $50 \quad \mathrm{~kg}$ yüksek zenginleştirilmiş uranyum çalınmasılyla gerçekleşmiştir. Litvanya' da çalınan nükleer madde, olaydan bir süre sonra bir ormanda ele geçirilmiştir (Harmon, Christopher, 2001, s. 171). 1987 yılında Brezilya'nın Goyaniya kentinde sezyum 137 yüklü çalınmış konteynırın zedelenmesi sonucunda 4 kişi ölmüş, 120 kişi zehirlenmiş, 200 kişi evlerini terk etmek zorunda kalmıştır. Çevrenin maddeden temizlenme süresi 6 ay sürmüş, 575 uzmanın yardımıyla 3500 metreküp radyoaktif atık çıkartılmıştır (Belous, 2004). Haziran 2003'te Amerika ve Tayland istihbarat servisleri tarafından yüksek radyoaktif içeren sezyum 137 yüklü birkaç konteynır bulunmuştur. Soruşturma sonucunda bu tehlikeli yükün devlet liderlerinin buluşacağı büyük Asya ekonomik toplantısı sırasında yapılacak terörist eylemler için hazırlandığ öğrenilmiştir (Belous, 2004). 
Nükleer silahların en büyük kaynakları Rusya sınırları içerisindedir ve silahların çoğu gerektiği şekilde korunmamaktadır. Nükleer tesislerinin güvenlik sistemleri için ayrılan paraların yeterli olmaması, çalışan personelin maaşlarının düşük olması tehdidin boyutunu yükseltmektedir. Bu açıkların Çeçen ayrılıkçılar dâhil olmak üzere diğer teröristler tarafından kullanılabilme riski büyüktür.

Rusya'daki nükleer terörizm riski Çeçenistan Savaşları ile artmıştır. Çeçen Savaşları sırasında birkaç kez Çeçen teröristler tarafından kitle imha silahı kullanılarak gerçekleştirilecek eylem tehdidi gelmiştir. Bu tehditler hiç de asılsız değildir. Çünkü Çeçenistan sınırları içerisinde, Karah Dağları civarında (Groznıy ilinin kuzeydoğu tarafında) radyoaktif maddelerin gömüldügü ve Kuzey Kafkasya ülkeleri tarafından nükleer atıkları saklamak için kullanılan özel "radon" deposu vardır. Orada saklanan maddelerin radyoaktifliği 1600 kür olarak değerlendirilmektedir. "Radon" depolarında kobalt 60, sezyum 137, tulyum 170, iridyum 192 gibi radyolojik ve nükleer maddeler saklanmaktadır. Çatışma "radon" üzerindeki kontrolün kaybolmasına neden olmuş; bu da federal yönetimin tedirginliğine yol açmıştır. Durum, çatışma sırasında deponun kontrolünün geri alınmasıyla değişmiştir (Baker, Lloyd, 2001).

Moskova'ya karşı çıkan Çeçenistan Başkanı Djohar Dudaev daha 1992 yılında nükleer silah kullanarak eylem gerçekleștirme projelerini hazırlamaktaydı. Bunun için Rusya Deniz Kuvvetleri'ne ait Dalniy Vostok'taki nükleer denizaltı gemisini ele geçirmeyi planlamıştı. Projeye göre Slav tipi yedi Çeçen terörist Vladivostok'taki askeri gemiyi ele geçirecekti; nükleer reaktör ve nükleer başlıklı füzelerden birine bomba yerleştirdikten sonra Rus askerlerinin Çeçenistan'dan çekilmesini talep edecekti (http://www.globalaffairs.ru/articles/0/3069.html, 18.10.2004). Planın gerçekleştirilmesine engel olundu; fakat terörist liderleri arasında bulunan İslam Haşuhanov'un geçmişte Rusya Deniz Kuvvetleri'nin denizaltı gemilerinin birinde çalıştığ 1 dikkate alınırsa bu projenin engellenememesi durumunda ne denli büyük facialara yol açılabileceği açıktır (http://www.globalaffairs.ru/articles/0/3069.html, 18.10. 2004).

\subsection{Nükleer Silahların Çalınması}

Bütün dünyada yaklaşık 30.000 nükleer silah bulunduğu bilinmektedir. $\mathrm{ABD}$ ve Rusya hâlâ en çok nükleer silah bulunduran ülkelerdir. Rusya'da nükleer silah bulunduran askeri birimlerin çoğunun çalınma ihtimaline karşı güvenli bir şekilde korunmasına rağmen silahların yarısı gerektiği şekilde korunmamaktadır. Bu da El Kaide, Aum Shinriki gibi terörist gruplara firsat yaratmaktadır. Nükleer silahlar, Aum Shinriki ve El Kaide gibi terörist örgütlerin en büyük hedefleridir. 1990'l1 yıllarda iki örgüt, eski Sovyetler Birliği ülkelerinden birkaç kez bu tür silahları elde etmeye çalışmışlardır. Örgütlerin nükleer silahlara ulaşma çabalarının bugüne kadar başarısızlıkla sonuçlanmasına rağmen ileri zamanlarda ulaşabilme ihtimali yüksektir. Çoğu devlet söz konusu maddeleri güvenli bir şekilde korumakta ve kontrol etmektedir. Fakat bazı ülkelerin güvenlik tedbirleri daha düşüktür. $\mathrm{Bu}$ da tehlikenin boyutlarını ciddi bir şekilde etkilemektedir. Eski Sovyetler Birliği’nden kalan kitle imha silahları bu konularda daha hassastır; bu tür silahların boyutlarının daha küçük olduğu göz önüne alınırsa teröristler tarafından çalınmaları açısından daha uygun hedefler olduğu ifade edilebilir (http://www.globalaffairs.ru/articles/0/3069.html, 17.09.2001). 


\subsubsection{Nükleer Atıkların Silah Üretiminde Kullanma Amaçlı Çalınması Veya Başka bir Yolla Elde Edilmesi}

Nükleer atıkların elde edilmesi, teröristleri nükleer silah sahibi olmaya götürebilecek ikinci yoldur. Silah üretiminde kullanılan nükleer maddeler yüksek zenginleştirilmiş uranyum, uranyum 233 ve platondur (\% 80 izotop 238 içermeli). Fakat teröristlerin nükleer silah üretiminde bu tür maddeler en büyük engeldir. Nükleer maddelerin elde edilmesi çoğu terörist örgütün imkânlarını aşmaktadır. Buna rağmen eski Sovyetler Birliği ülkelerinden nükleer maddeleri ve gerekli teknolojiyi bulabilmenin mümkün olabildiği konusunda hâlâ endişeler vardır. Rusya'da 250 ton yüksek zenginleştirilmiş uranyum ve 50 ton plütonyum depolanmış olduğu gerçeğinden hareketle, hassas nükleer maddelerin depolama tesislerinden yasadışı yollarla alınma riski ciddi bir tehlike olarak görünmektedir. Ancak terörist bir grubun nükleer maddelere sahip olması gibi bir durumda bile kitle imhası yaratma kapasitesine sahip bir nükleer araç yapabilmek için eğitimli ve üstün yetenekli bir personele, büyük miktarda paralara, gelişmiş tesislere ve ekipmana, ayrıca sıkı bir güvenliğe ihtiyaç vardır. Bu denli karmaşık ve çok sayıda unsurun bir araya gelmesini zorunlu kılan etkin bir nükleer silah yapım programı, terörist grubun istihbarat birimleri tarafından ortaya çıkarılma riskini de arttırmaktadır (http://www.cryptome.org/tpterr.htm, 17.02.2002). Bunlara rağmen teröristlerin nükleer silah taklitlerini yapabilme ihtimali yüksektir. Bunlar askeri silahlardan daha basit, fakat büyük kayıplara yol açabilecek kapasitede olabilirler. Üstelik bu tür silahların üretimi için açık bulunabilecek bilgilerden daha fazlası gerekmemektedir. Taklit silahların uranyum U 35 içeren basit bomba türünde üretileceği tahmin edilmektedir. Fakat bu silahların üretimi için büyük miktarda, yaklaşık 50 kilogram kadar yüksek zenginleştirilmiş uranyum gerekmektedir. Terörist örgütlerin devlet yardımı olmadan silah üretimi için gerekli maddelere yeterli miktarda ulaşabilme ihtimali düşüktür. $\mathrm{Bu}$ yüzden en büyük tehlike devletlerin silah üretim atıklarının terörist örgütlerin eline geçmesidir.

Nükleer silah ve madde çalınmasının yanında yeterince büyük risk taşıyan ve analizinin yapılmasını gerektiren konulardan biri de nükleer tesislere yönelik saldırılar ve kaza sonucu kaybolan nükleer silahlardır. Bugünlerde yasal olmayan yollarla ne kadar radyoaktif ve nükleer madde taşındığına dair hiçbir resmi bilgi yoktur. Uluslararası Nükleer Enerji Ajansı tarafindan 2001 yılında bu konuda 550 olay kaydedilmiştir. Bu araştırmaya katılan devletlerden sadece üçte ikisi radyoaktif ve nükleer madde transferini doğrulamıştır (http://www.zerkalo-nedeli.com/nn/show/371/33091/, 7.01.2001). Bunun dışında tıp ve sanayide kullanılan radyoaktif maddelerin kontrolsüz kalması, bu tür kaynakların binlercesinin kaybolmasına yol açmıştır ve terörist örgütlerin bunları elde etmesi kolaylaşmıştır (Belous, 2004). Bunlara istinaden aşağıda nükleer tesislere yapılan saldırılar ve kaza sonucu kaybolan kitle imha silahlarının tehdit boyutları ele alınmıştır.

\subsubsection{Reaktör Veya Diğer Nükleer Tesislerine Yönelik Saldırılar}

Terörist örgütler, nükleer silah, uranyum ve platon elde etme hedeflerine ulaşabilmek için nükleer tesislere büyük bir ilgi duymaya başlamışlardır. Bunların birkaçına yapılacak saldırıların nükleer silah 
saldırısı ile eş değer etki yapabileceği düşüncesi ile harekete geçmektedirler. Teröristlerin nükleer santrallere yönelik saldırıları Çernobil kazalarına benzer bir felaketin ortaya çıkmasına sebep olabilir (Çernobil kazası Nisan 1986'da SSCB'de Kiev yakınlarındaki Çernobil reaktöründe ortaya çıkan patlamadır. Hasar gören reaktörden sizan radyoaktif parçacıların oluşturduğu dev bir bulut Avrupa'nın içlerine, 2.000 kilometrelik bir uzaklı̆̆a yaylldı. SSCB'de 31 kişinin öldü̈̆̈̈, 200 bin kadar kişinin de evlerini terk etmek zorunda kaldığ ortaya çıkan bir başka etki de, atmosferden yeryüzüne inen radyoaktif parçacıkların SSCB'de ve çevre ülkelerde toprağın ve suyun kirlenmesine neden olmaslydl. Bkz, Temel Britannica Ansiklopedisi, Cilt 13, s. 121-122). Her sene artan nükleer atıklar tehlikenin boyutlarını yükseltmektedir. Şu an atıkların 200 bin tonu aştığı bilinmektedir; 2010 yılında 350 bin tona ulaşacağı düşünülmektedir. Sadece 1000 megabaytlık bir reaktör bir yılda 40-50 tane nükleer silah üretimi için yeterli miktarda platon çıkartabilir (http://usinfo.state.gov/journals/itps/0305/ijpr/cameron.htm, 2005).

Bugünlerde nükleer yakıt ve atıkların yeniden işlenmesi gündemdedir: Nükleer enerji dünyanın en büyük elektrik enerjisini üretmektedir. 30 ülkede 438 nükleer, 652 bilimsel amaçlı kurulan nükleer reaktör çalıştırılmaktadır. Bütün bunlar nükleer maddelere ulaşımı kolaylaştırmakta ve radyoaktif atıklarından radyolojik silah üretim ihtimallerini yükseltmektedir. Tek bir nükleer istasyonun teröristler tarafından ele geçirilmesi, halk arasında büyük bir psikolojik etkileşim yaratması için yeterlidir. Başka bir ifadeyle, teröristler tehditlerini sonuna kadar gerçekleştirmeden istedikleri sonuçlara ulaşabilirler (http://www.zerkalo-nedeli.com/nn/show/371/33091/, 7.01.2001).

11 Eylül 2001 tarihinde teröristlerin uçakla Pensylvania Eyaleti'ndeki nükleer santralleri bombalamaya çalıșmaları, teröristlerin ileride de bu tür eylemlerde bulunabileceği ihtimalinin yüksek olduğunun önemli bir göstergesidir (Belous, 08.10.2004). Teröristlerin nükleer silah hedeflerine ulaşmak için diğer bir ilgi odağı da bilimsel amaçlı kullanılan reaktörlerdir. Teröristlerin bu tür reaktörlere ilgi duyması iki nedenle açıklanabilir: Birincisi, reaktörler yüksek seviyede uranyum içermektedir (her birinde 10 kilogramdan 50 kilograma kadar yüksek zenginleştirilmiş uranyum bulunmaktadır). Bunların yardımıyla patlayıcı madde içeren silahlar üretilebilir. $\mathrm{Bu}$ tür silahlar Amerika tarafından Hiroşima'nın bombalanması için kullanılmıştır.

Uzmanların verdiği bilgilere göre, dünyada 200 'den fazla reaktör bulunmaktadır (http://info.trud.ru/shortnews.php?id=18782, 30.10. 2005).

İkincisi, reaktörler daha az korunmaktadır: Bu reaktörler, aralarında teröristlerin de olabileceği geniş bir kitleye ve bilim adamlarına açıktır. Radyoaktif izotop içeren reaktörlere yönelik saldırılar "kirli bomba" etkisi yaratarak çevrenin kirlenmesine de yol açabilirler.

Reaktörlerin, şehir içindeki bilimsel araştırma merkezleri veya üniversite kampusları yakınlarında olmasından dolayı tehdit boyutu daha yüksektir. Reaktörler özellikle çatışma sırasında büyük bir risk taşımaktadır. Örneğin Irak, Kuveyt'e saldırmadan önce, 1991 yılında Basra Körfezi yakınlarında Fransa tarafindan kurulan reaktörden alınan 36 kilogram uranyum yakıtı ile nükleer silah üretmeye çalışmıştır (http://info.trud.ru/shortnews.php?id=18782, 30.10.2005). 


\subsection{Kaza Sonucu Kaybolan Nükleer Silahlar}

Nükleer terörizm tehditlerine yol açan diğer nedenlerden biri kaza sonucu kaybolan nükleer silahlardır. Nükleer silahlara sahip SSCB ve Amerika'nın nükleer silah kayıpları olduğu bilinmektedir. Soğuk Savaş sırasında toplam 40 tane nükleer başliklı füzenin bulunduğu 4 Sovyet nükleer denizaltı gemisi batmıştı. Basının açıklamalarına göre denizaltıların biri ancak dev "Glomar Explorer" gemisi yardımıyla çıkartılmıştır. Bunun dışında 3 nükleer başlıklı füze ve iki nükleer torpedo silahı çıkartılmıştır http://www.fas.org/irp/program/collect/jennifer.htm, 29.04.2004). Amerika Savunma Bakanlığı da "kırık oklarının" (Amerikan Silahlı Kuvvetleri tarafından kaybedilen nükleer silahlar) olduğunu itiraf etmiştir; fakat hiçbir zaman ilgili rakamları bildirmemiştir. Kayda geçen kayıplardan biri 1965 yılında B43 numaralı askeri uçağın Japonya yakınlarında kaza sonucu düşmesi ve Japon Denizi'nde batmasıyla gerçekleşmiştir. 1966 yılında Amerikan Hava Kuvvetleri'ne ait askeri uçak İspanya'nın Palomares kasabası yakınlarında kazayla Akdeniz'e 20 megaton nükleer bomba düşürmüştür. Üç aylık kesintisiz aramalar sonucunda bomba bulunmuştur.

Fakat bu tür olayların hassasiyetini göz önüne alarak bu açıklamaların aysbergin ancak su üstünde kalan kısmı olduğu tahmini yürütülebilir (http://www.globalaffairs.ru/articles/0/3069.html, (18 Ekim 2004).

\section{TERÖRİST ÖRGÜTLERİNIN NÜKLEER SİLAH YAPMA İHTIMMALİNİN DEĞERLENDİRİLMESİ}

Bazı uzmanlar, teröristlerin nükleer maddelere ulaştığı varsayılsa bile bunun etkili bir nükleer silah yapabilmek için yeterli olmadığını belirtmektedirler. Nükleer silah yapımı için nükleer maddelerin yanısıra bilgi, endüstriyel altyapı ve nükleer silah programını sonuca taşıyacak kaynaklar gerekmektedir; bu da birçok maddenin çoğu ülkede hâlâ üretilmemesinden dolayı teröristleri bütün kaynakları bir araya getirme zorluğuyla karşı karşıya getirmektedir.

Örneğin Irak'ın, zamanında elinde silah yapımı için gerekli nükleer kaynaklar olmasına ve üretim için milyarlarca para harcamasına rağmen bunu başaramadığı bilinmektedir. CIA'in verdiği bilgilere göre, nükleer maddelerin diğer ülkelerden çalınması veya satın alınması halinde nükleer üretimin zamanlaması birkaç aydan birkaç seneye kadar azalabilir (http://www.cia.gov/cia/reports/iraq_october_2002.htm, 17.05.20). Fakat bu argümanda etkili bir nükleer silah yapımı ile nükleer silahların basit bir taklidi arasındaki önemli fark gösterilmemektedir. Etkili bir nükleer silah füze veya askeri bir uçak yardımı ile getirilebilmektedir; yani bu bir devletin silah deposunda bulunmasını istediği etkili bir nükleer silahtır. İkincisi de kamyon veya gemi ile taşınabilen hafif ve daha küçük silahlardır.

Los Alamos nükleer program araştırma laboratuarı ve "Manhettan" proje yöneticisi Hans Bet, zamanında Hiroşima'yı yeryüzünden silmesi için yeterli olan basit bir nükleer bombanın daha sonra bir bilim adamı ve iki doktora öğrencisi tarafindan yapıldığını bildirmiştir (Bomba yapımında plütonyum kullanılmıştır. Plütonyum içeren bombalar bir şehri yeryüzünden silme kapasitesine sahiptir, http://www.books.nap.edu/books/30908/html/156.html, 29.04.2004 ). Bu tür bombaların yapımı çok basittir; yapımı sırasında çözülmesi zor şemaların kullanılmasına ve silahın 
denenmesi için gereken büyük masraflara başvurmaya, başkaları tarafından öğrenileceğinden korkmaya gerek yoktur; ayrıca kullanımda etkili olacağından hiç şüphe yoktur (6 Ăgustos 1945 yılında Hiroşima'ya düşürülen dört ton ă̆ırlığındaki bombanın etkili olacağından hiçbir şekilde şüphe duyulmadığı için herhangi bir deneme yapılmadan kullanılmıştır, http://nvo.ng.ru/concepts/2004-10-08/4_terrorism.html, 8.10.2004).

"Teröristler nükleer silah yapabilecekler mi?" sorusunu araştıran Amerikalı bilim adamları, yapabilecekleri kanaatine varmaktadırlar. $\mathrm{Bu}$ nükleer silahların iki türü için de geçerlidir. Bu sonuçlar uzmanlar tarafından 11 Eylül terörist saldırılarından önce de belirtilmiştir (http://www.nci.org/km/makeab.htm, 29.04.2004). ABD Teknolojik Araştırma Ofisi'nin detaylı analizi sonucunda, teröristlerin nükleer silah yapımı için gerekli gizli bilgiler olmadan da basit nükleer silah yapabilecekleri açıklanmıştır. Bunun için çok miktarda teknik teçhizatın olmasına veya denemelerin yapılmasına gerek yoktur. Bunun için hiç şüphe uyandırmadan kiralanan küçük bir atölye de yeterli olabilir. Finanse edilmesi için de büyük miktarda paralara ihtiyaç duyulmamaktadır. $\mathrm{Bu}$ grubun içine araştırma yapabilecek ve ilgili kaynaklardan anlayabilecek bir teknik uzmanın dâhil olması yeterlidir (http://www.wws.princeton.edu/cji-bin/byterserc.prl/-ota/disk3/1977/7705_n.html,

29.04.2004, s. 140). Yüksek zenginleştirilmiş uranyum kullanarak yapılan silahlar çabuk patlamaktadır; bu yüzden Amerikan Enerji Bakanlığı nükleer tesislerin teröristlere karşı ciddi bir şekilde korunması kuralını sıkı bir şekilde takip etmektedir. $\mathrm{Bu}$, teröristlerin nükleer tesislerden kaynak çalmasını veya patlama organize etmesini engellemek için yapılmaktadır (http://www.fas.org/Irp/doddir/doe/m5632_1c-1/m5632:1c-cl.htm, 29.04. 2004 ). Bu tür silahların teröristler tarafından yapılabileceği ihtimalini ölçmek için analistler tarafindan sadece araştırmalarla yetinilmeyip küçük bir denemeye de başvurulmuştur. 1977 yılında Princton Üniversitesi öğrencisi yılsonu ödevi olarak nükleer tipte bir bomba yapmıştır. Öğretmenliğini yapan "Manhettan" emektarı Frimen Dayson öğrencinin çalışmasını başarılı olarak değerlendirmiştir; daha sonra bu çalışma devlet tarafından gizlenmiştir (Philips, Michaelis, 1978).

Yapılan diğer deneyler de bu tür silahların nükleer silah yapımı ve patlayıcı maddeler hakkında hiçbir bilgisi olmayan kişiler tarafından da yapılabileceğini göstermiştir (http://www.thebulletin.org/past_issues/059_002htm, 29.04.2004).

Elbette nükleer silahlar ile yakından ilgilenen bir uzmanın yardımı teröristlerin nükleer silah yapım faaliyetleri için faydalı olacaktır. El Kaide ve taraftarlarının bu tür yardımlar için aktif bir uzman arama girişiminde bulundukları bilinmektedir. Usame Bin Laden ve yardımcısı Ayman Al Zavahiri'nin nükleer bomba yapımı için gerekli bilgileri almak amacıyla uzunca bir dönem Pakistanlı nükleer silah uzmanları Sultan Başiruddin Mahmut ve Çaudari Abdul Madcit ile görüştükleri bilinmektedir. Bu iki bilim adamı Talibanları ve radikal İslam görüşlerini desteklemektedir. Bilim adamları daha sonra Bin Laden ve Ayman Al Zavahiri ile görüştüklerini itiraf etmişlerdir; fakat silah yapımı ile ilgili hiçbir bilgi vermediklerini söylemelerine rağmen Pakistan istihbarat servisi Washington Post Gazetesi'ne ikili tarafından Pakistan'ın gizlilik kanunları çiğnenerek Bin Laden'e detaylı bir şekilde bütün teknik bilgilerin verildiğini açıklamıştır.

1998 y1lında önemli nükleer tesislerin birinde Taliban ve Irak'a nükleer silah yapımı ile ilgili bilgileri satan Rus bilim adamı tutuklanmıştır 
(http://www.nti.org/cnwm, 5.02.2005). 2000 y1lında Rusya Güvenlik Bakanlığ1, Talibanların Rusya nükleer tesislerinden Rus nükleer uzmanlarından birini kaçırma teşebbüsünde bulunduklarını açıklamıştır (Douglas, Josh, 2004).

Bazı uzmanlar, 11 Eylül olaylarından sonra El Kaide örgütüne yönelik saldırılar ve takip sonucu örgütün faaliyetlerinin zayıflatıldığını ve etkili bir nükleer bomba yapmak gibi uzun süreli bir projeye gücünün yetmeyeceğini belirtmektedirler. Öncelikle, örgüt üyeleri ileri teknoloji ve nükleer silah konusunda yeterli bilgiye sahip değildirler. Örneğin 1999 yılında Afganistan'da, El Kaide örgütünün uzmanlardan yardım almadan kendi imkânları ile sinir gazı yapma girişimlerinin başarısızlıkla sonuçlandığını bildiren bir rapor bulunmuştur. Raporda bu tür faaliyetler için uzmanların bulundurulması tavsiye edilmiştir (http://www.nti.org/CNWm, 02.02.2005). Fakat örgüt liderleri arasında teknik bilgilere sahip olanlar da vardır. Örneğin Usame Bin Laden'in yardımcısı Al Zavahiri doktorluk mesleğine sahiptir, 11 Eylül saldırılarının baş organizatörlerinden Halit Şeyh Muhammet Amerika'da eğitim almış bir mühendistir (http://www.nti.org/CNWm, 2.04.2005). Bu grup birkaç kez aç1kta bulunan kaynakları kullanarak zor deneyler yapabilme imkânlarını sergilemiştir (El Kaide'nin aktif biyolojik silah arayışları ve araştırmaları hakkında bilgiler Afganistan'da bulunan açık kaynaklardan alınmıştır, Petro, Relman, 2003, s. 1989). Açığa çıkarılan El Kaide nükleer program analizlerinin birinde bu grubun Afganistan'da hareket ettiği süre içinde gerçek bir tehdit oluşturduğu ve bir başka yerde de başarılı olabileceği sonucuna varılmıştır (http://www.nti.org/CNWm,2.02.2005).

11 Eylül sonrası El Kaide terör örgütüne karşı yapılan operasyonlar sonucunda üyelerin çoğu tutuklanmış ya da öldürülmüş; operasyonları ise bozulmuştur. Bütün bunlar El Kaide'nin nükleer silah kullanarak saldırıda bulunabileceği ihtimalini azaltmıştır. Taliban rejiminin kaldırılması ve örgütün Afganistan'daki sığınaklarının yok edilmesi El Kaide'nin nükleer programlarına ciddi derecede zarar vermiştir. Fakat burada iki önemli hususun göze alınması gerekmektedir: Bunlardan birincisi daha önce de belirtildiği gibi, basit bir nükleer patlayıcı yapmak için fazla bir teçhizat gerekmediğidir; ikincisi de uzmanların verdiği bilgilere göre, bu tür silahların yapımı için çok az zaman gerektiğidir.

Terörist gruplar deneme ve silah yapımı için toplumun dikkatini çekmeyecek ve şüphe uyandırmayacak basit yerleri tercih etmektedirler. Nükleer silahların montajının yapıldığı Güney Afrika'daki bina sıradan bir depo gibi görünmektedir (Silahların montajı birinci katta, $400 \mathrm{~m} 2$ bir bölmede yapılmaktaydl. Güney Afrikalılar özellikle dikkat çekmemek için bu tür binaları seçmişlerdi. Binanın tek özelliği yoldan görünmemesi için toprak yığınları ile kapatılmasıdır. Albright, 2004). Denemeler için yapılan dünyanın ilk bombası bir kulenin zemin katında yapılmışıı (Hoddeson, Henriksen, Paul, Meade, Westfall, 1993, s. 367-370). Bunların dışında teröristlerin rahat bir şekilde faaliyetlerini sürdürebilecekleri çeşitli bölgeler vardır; örneğin Afganistan dağları veya Somali gibi zayıf ülkeler bu bölgeler arasındadır. CIA yöneticilerinden Tenet, Senato Komitesi'nde yaptığı bir konuşma sırasında, merkezi hükümetin ulaşamadığı birçok bölgenin olduğunu belirtmiştir. Verilen bilgilere göre, 50 devlet içinde bu tür "kanunsuz bölgeler" vardır (http://www.nti.org/CNWm, 4.02.2005). 


\section{KITLE İMHA SILAHLARININ KORUNMASI İÇIN ALINAN TEDBIRLER}

Nükleer silah türlerinden nükleer başlıklı silahlar büyük, kolaylıkla taşınmaz olduklarından ve bu silahlara devletler tarafindan uygulanan sıkı güvenlik tedbirleri nedeniyle ulaşmak çok güçtür. Nükleer silahların çoğunda Amerikan silahlarına özel elektronik kilit (PAL) uygulanmıştır. $\mathrm{Bu}$ tür kilitlerin özelliği, gereken şifre girilmezse bombanın etkinlik dışında kalmasıdır. Bugün bu tür kilitler bütün modern silahların bir parçası haline gelmiştir. Ayrıca silahlarda "deneme sınırı" uygulanmıştır; yani şifre birkaç kez yanlış girilirse bu mekanizma otomatikman bombayı etkisiz hale getirmektedir (Stein, Feaver, 1992). Bunun dışında çoğu nükleer silah, kazaya ya da yetkisiz kişiler tarafından kullanılmasına karşı tasarlanmış ihtiyati ("permissive") hareket bağlantıları ya da kendi kendini yok etme mekanizmalarına sahiptir. Teröristlerin, silahlara yerleştirilmiş bu koruyucu mekanizmaların üstesinden gelmesi ise çok zordur (http://www.cryptome.org/tpterr.htm, 17.02.2002). Bu tür güvenlik önlemleri eski Sovyet silahları için geçerli değildir. Bu yüzden de ABD ve Rusya'da eski model nükleer silahların çoğu silah deposundan kaldırılmıştır. Tehlikeli eski model silahlar büyük ihtimalle imha edilmiştir; fakat bu kesin bir delil değildir; çünkü ülkelerin hiçbiri bunları yapacağına dair bir taahhüt vermemiştir. Pakistan, Hindistan ve Çin devletlerinin kendi nükleer silahları için "PAL" tipi güvenlik tedbirleri almadığına dair şüpheler vardır; fakat bir diğer ihtimal silahların parçalanmış şekilde saklanabileceği yönündedir.

Kitle imha silahlarının teröristlerin eline geçmesini önlemek için alınan uluslararası tedbirler arasından 1 Mart 1991 tarihinde Keşif Amaçlı Plastik Patlayıcıların Markalanmasına Dair Montreal Sözleşmesi imzalanmıştır (Convention on the Marking of Plastic Exposives for the Purpose of Detection), (http://www.un.org/russian/markonv.html, 2003). Sözleşmeye taraf olan ülkeler plastik patlayıcı üreticilerinin bu patlayıcıları işaretlemelerini sağlamakla ve işaretlenmiş patlayıcıların sınırları içerisinde dolaşımını engellemekle yükümlüdür. Sözleşme sonrasında patlayıcıları kontrol altında tutmak için uluslararası komisyon kurulmuştur.

15 Aralık 1997'de 24 maddeden oluşan Terörist Bombaların Önlenmesine Dair Uluslararası Sözleşme kabul edilmiştir (İnternational Convention for the Suppression of Terrorist Bombings), (http://www.un.org/russian/markonv.html, 2003). Bu sözleşme Birleşmiş Milletler Genel Kurulu tarafindan 15 Aralık'ta 52/164 sayılı kararla kabul edilmiş, 23 Mayıs 2001'de yürürlüğge girmiştir.

\section{RADYOLOJIK, KIMYASAL VE BIYYLOJIKK SİLAHLARIN TERÖRISTLER TARAFINDAN KULLANMA TEHDIDININ ANALIZI}

11 Eylül sonrasında teröristlerin amaçlarına ulaşmak için kendi canlarından olmaya hazır bir duruma geldiği ortaya çıkmıştır. Bu yüzden her ne kadar teröristler için de bu tür silahların büyük bir tehlike içerdiği düşünülse de bunları göze alarak eylem planlarını sürdürmeye hazır olan teröristlerin var olduğu da bir gerçektir. Tüm bunlar dünyanın her an teröristler tarafından yaratılabilecek facia ile karşı karşıya kalabileceğinin göstergesidir. Olas1 bu tür felaketleri önleyebilmek için teröristlerin ulaşabilecekleri ve saldırılarda kullanabilecekleri kimyasal silahlar incelenerek olası kullanım ihtimalleri araştırılmalıdır. 


\section{Radyoaktif Silahlar}

Radyolojik silahlar geçtiğimiz dönemlerde teröristler için öncelikli seçeneklerden değildi. Fakat bu tür silahların insanlar ve çevre üzerinde, başta genetik bir takım etkiler olmak üzere uzun vadeli sonuçlar doğurabileceği anlaş1lmıştır (http://www.csis.org,15.02.2001). Teröristlerin, nükleer silahların elde edilmesinin zorluklarını göze alarak belirli bir coğrafya üzerinde kirlilik yaratmak için çevreye radyoaktif madde yayma teşebbüsünde bulunmaları daha olası bir seçenek gibi görünmektedir. Diğer taraftan radyoaktif maddeleri taşımak, depolamak ve etkili biçimde yaymak çabasında olan teröristlerin kendileri için de çeşitli güvenlik riskleri mevcuttur. Radyoaktif maddeler, kirli bombalar gibi radyolojik yayma araçları ile yayılabileceği gibi gıda ve su kaynaklarını kirletmek için de kullanılabilir. Ancak ikinci seçenek için büyük miktarda radyoaktif maddeye ihtiyaç duyulacağından bunun gerçekleşebilmesi çok daha güçtür. Ayrıca radyoaktif maddeler çözülebilir olmadığından şehir su şebekelerini kirletmek gibi amaçlar için kullanılmaları pratik bir yol değildir. Radyolojik silahlar, özellikle cesium 137, iridyum 192 ya da kobalt 60 gibi radyoaktif maddelerin insanlar üzerinde öldürücü ve yaralatıcı etkileri olabilmektedir. İnsanları kitlesel olarak öldürme kapasitesine sahip olmasa da bir radyolojik silah, kendisi ile temas eden kişilere zarar vermenin yanı sıra önemli tesisleri ve altyapıları, koruyucu kıyafetler giymeden girilemez ve kullanılmaz hale getirmek için kullanılabilirler. Böyle bir saldırı, oldukça büyük ekonomik ve ticari zararlara yol açabilir.

\section{1."Kirli Bomba"}

"Kirli bomba" yapımı için en düşük kalitedeki nükleer maddeler kullanılabilir. $\mathrm{Bu}$ kategoriye giren maddeler hem sivil hem askeri sektörlerde bulunmaktadır (Örneğin tıpta röntgen için kullanılan sezyum). $\mathrm{Bu}$ yüzden de silah için kullanılan maddelerden daha az korunmaktadır ve terörist örgütler tarafından elde edilmesi daha kolaydır. Bütün bu imkânlar, radyoaktif maddeleri teröristler için ulaşabilmesi en kolay silah haline getirmektedir; çünkü bu silah patlayıcı maddenin yanında sadece bir radyolojik kaynak fonksiyonunu görecektir. Radyolojik madde kullanarak yapılan eylemlerin bir örneği 1995 yılında Çeçen teröristlerin Moskova parklarının birine cesium 137 dolu bir kutu bırakmasıydı (http://bsia.ksg.harvard.edu/BSİA_content/document/saradzhyan_2003_02.pdf, 29.042004).

\subsubsection{Kimyasal Silahlar}

Birleşmiş Milletler'in 1969 yılındaki raporu kimyasal silah maddelerini "insanlar, hayvanlar ve bitkiler üzerindeki toksin etkileri nedeni ile kullanılabilecek gaz, siv1 ya da katı kimyasal maddeler" olarak tanımlamıştır. Kimyasal silahlar konvansiyonu bu tanıma kimyasal maddelerin yayılması için gerekli araç ve mühimmatı da eklemiştir. Kimyasal saldırı olasılığı, kimyasal silahların yapımında gerekli olan öncü kimyasal maddeler kolay elde edebildiğinden nükleer ve biyolojik maddelerin kullanım olasılı̆̆ından çok daha fazladır. Ayrıca, bir terörist grubun saldırı gerçekleştirmek için sofistike bir kimyasal yayma aracı yapması da zorunlu değildir. Uygun hava koşullarında gerçekleştirilen konvansiyonel bir sabotaj ya da bombalı saldırı ortaya çıkan toksin bulutun bir yaşam alanına doğru hareketini sağlayabilir. Böyle bir olayın sivil halk 
üzerinde yoğun miktarda korku, dehşet ve paniğe neden olması beklenebilir. Böylelikle temel bir terörist hedef gerçekleştirilmiş olacak ve bunun sonucu bir kimyasal silahın yol açacağı sonuç kadar tehlikeli olabilecektir (http://www.emergency.com/cbwlesnl.htm, 26.02.2002).

Kimyasal silahların kullanıldığı saldırılar iki şekilde gerçekleşebilir. Birincisi kitlesel tahribatı amaçlayan saldırılardır. $\mathrm{Bu}$ tür saldırılarda teröristler mümkün olduğunca fazla kurban yaratabilmek için insanların yoğun şekilde bulundukları merkezlere toksin madde yaymaktadırlar. Aum Shinriki'nin saldırısını gerçekleştirmiş olduğu yeraltı taşıma sistemleri, spor stadyumları, iş merkezleri, devlet binaları ya da çok sayıda insanın bulunabileceği diğer alanlar kimyasal bir saldırı için en uygun alanlardır. İkinci tip kimyasal saldırı ise ana hedefin korkutmak, şantaj yapmak ya da ekonomik zarara neden olmak için belirli bir ürüne, özellikle gıda ürünlerine yönelik olarak gerçekleştirilen saldırılardır (http://www.ict.org.il, 26.02.2002).

Kimyasal silah yapımında kullanılan kimyasal maddeler çeşitli özelliklere göre 4 farklı sınıfa ayrılmaktadır:

1. Kan maddeleri: Nefes alma esnasında ve sonrasında kanın oksijen taşıma özelliğine zarar veren hidrojen siyanid ya da siyanid klorid

2. Boğucu maddeler: Akciğeri etkileyen klorin ve fosgen

3. Kabartıcı (blistering) maddeler: Vücudun herhangi dış ya da iç bölümüne saldıran, vezikül oluşturan maddeler, hardal gazı

4. G ve V serisi sinir maddeleri: Sinir sisteminin vücudun işlev görme yeteneğini ortadan kaldıran tabun ( GA), sarin (GB), soman (GD); VX (http://www.cryptome.org/tp-terr.htm, 17.02.2002)

Bu silahların hepsi de öldürücüdür. Ancak, bu maddelerden herhangi biri kitlesel zayiata neden olabilecek saldırılar gerçekleştirmek amaciyla kullanılabilme potansiyeline sahip olsa dahi terörist gruplar bu maddelerin çoğunu kullanmayı reddetmektedirler. Klorin ya da fosgen gibi zehirli endüstriyel kimyasallar kolaylikla elde edilebilen maddelerdir ve kimyasal silaha uyarlanabilmeleri için üst düzey uzmanlığa ihtiyaç yoktur. Ancak bu tip silahlar ile kitlesel ölümler meydana getirebilmek için büyük miktarda kimyasal maddeye ihtiyaç vardır. Hardal gazı gibi kabartıcı maddeler de kolay üretilebilmektedir; ayrıca hardal gazının kitlesel ölümlerden ziyade yaralanmalara sebebiyet vermesi daha olasıdır (http://www.cryptome.org/tpterr.htm, 17.02.2002). V serisi sinir gazlarının üretilmesi daha güçtür ve çok sayıda öncü kimyasal sentezi gerektirmektedir. Bunun yanında, üretimi için yüksek sıcaklık gerektiren işlemler yapılmalıdır; ayrıca tehlikeli yan ürün yaratma riski içermektedir. $\mathrm{Bu}$ da maddelerin ancak çok gelişmiş laboratuarlarda üretilebileceği anlamına gelmektedir (Bowman, Barel, 2002). Diğer taraftan $G$ serisi bir sinir gazı olan sarin, çok zehirli uçucu ve üretilmesi $\mathrm{V}$ serisi ile karşılaştırdığında daha kolay bir maddedir. Aum Shinriki örgütünü sarine yönelten sebep de bu maddenin özellikleridir. Fakat sarinin sentez edilmesi diğer sinir gazlarından daha az karmaşık olsa da, bu maddeyi üretmek için gereken uzmanlık küçümsenmemelidir. Maddenin üretim sürecindeki güvenlik sorunlarını önleyebilmek için üstün uzmanlık, eğitim ve ekipman gerekmektedir. Sarini etkili biçimde yaymak için gerekli araçları geliştirmek, teröristler için maddenin kendisini üretmekten çok daha zordur. Sarinin yüksek uçuculuğu silahlaştırılmasını büyük ölçüde kolaylaştırmaktadır. Fakat kitlesel zayiat içeren bir eylem yapmayı planlayan 
teröristler, hedefledikleri alana yeterli miktarda gaz yayabilmelerini sağlayacak sofistike araçlara ihtiyaç duymaktadırlar. Hava sıcaklığı, rüzgar hızı, gazın terse dönme ihtimali ve diğer meteorolojik faktörler de bir sarin saldırısının etkinliği belirleyecek unsurlardır (Gilmour, 2002).

Kimyasal silah maddeleri 1s1, nem ve rüzgâra çok hassas olduğundan en etkili biçimde kapalı alanlarda kullanılabilmektedirler. Zira sarin ve diğer kimyasal maddeler, çevreye yayıldıklarında rüzgar tarafından dağıtılmaya eğilimli olduklarından belirlenen hedefin yeterli derecede doza maruz kalmasını temin etmek için büyük miktarda kimyasal maddeye ihtiyaç vardır. Ancak 1000 kiloya varan miktarda sarin gazı kullanarak yapılan saldırının zararı, konvansiyonel patlayıcılar gibi geleneksel terörist araçların kullanılması sonucunda ortaya çıkan zararları aşabilir. $\mathrm{Bu}$ yüzden de saldırılar kapalı bir stadyum, iş merkezleri veya yeraltı ulaşım sistemlerinde gerçekleştirilmektedir (Gilmour, 2002).

Aum Shinriki'nin kimyasal silahlar konusundaki tecrübesi bu durumu somutlaştırmaktadır. Grup, sarin sentezlemek için gerekli teknik bilgiye, ekipmana ve kimyevilere sahipti. $\mathrm{Bu}, 30$ milyon doları aşan bir araştırma ve geliştirme çabası sonucunda gerçekleştirilmişti. Fakat Aum Shinriki Tokyo metro saldırısı ve daha önce Matsumoto'da gerçekleştirdiği saldırı ile yalnızca 12 kişiyi öldürmeyi başarmıştır (Turan, 2002, s.91). Eylemin arkasında yüzlerce yaralı ve psikolojik travma geçiren insan bırakılsa da Kenya ve Tanzanya'daki ABD Büyükelçiliklerine yapılan saldırıların ortaya çıkardığı 301 ölü ve 5000 yaralının yanında teröristler için parlak bir sonuç değildir. Bu yüzden çok sayıda insana zarar verme amaçlı harekete geçen teröristlerin kimyasal bir silah geliştirmek ve kullanmak yerine konvansiyonel silahlar kullanarak daha büyük felaketlere yol açabilme ihtimalleri yüksektir. Kimyasal silahların kitlesel ölçekte kullanımı oldukça zor olsa da kimyasal maddelere maruz kalan ölümlerin ötesinde bu tür saldırılar psikolojik bir kriz yaratacak ve saldırıya uğrayan ülke vatandaşlarının güvenlik hislerinin ortadan kalkmasına neden olacaktır.

\subsubsection{Biyolojik Silahlar}

Biyolojik silahları diğer silahlardan ayırt eden özellik, biyolojik silah araştırmaları hakkındaki bütün kaynakların açıkça kütüphanelerde rahatlıkla bulunabilmesidir. $\mathrm{Bu}$ da teröristlerin yeniden silah icat etme sorununu kolaylaştırmaktadır. Ayrıca biyoloji alanındaki çeşitli uluslararası projeler vasıtasıyla yoğun bir bilgi alışverişi gerçekleşmektedir. Teröristlerin bilgilere rahatça ulaşabilmesi, saldırı için gerekli uzmanlığı elde edebilme ve saldırıya geçme ihtimalini arttırmaktadır (http://www.cbaci.org, 9.10.2001).

Teröristlerin biyolojik saldırılarda kullanmak üzere biyolojik silah maddelerini elde edebilmelerinin çeşitli yolları vardır. Bunların arasında biyolojik maddeleri, dünyada yaklaşık 1500 tane bulunan mikrop (germ) bankalarının birinden satın almak, tedavi amaçlı üretilen laboratuar ya da hastanelerden çalmak, doğal kaynaklardan kültürlemek ya da terörizmi destekleyen başka bir devletten temin etmektir.

Biyolojik maddeler teröristlere önemli avantajlar sağlamaktadır. Biyolojik bir saldırı, konvansiyonel bir bombanın aksine ani bir ilgi çekmez ve saldırının farkına olaydan haftalar sonra varılabilir. 
Biyolojik silahların teröristler tarafindan kullanılma olasıllı̆̆ panzehirleri ve karşı önlemleri bulunan bir kimyasal maddenin yayılmasından çok daha korkutucu görülmektedir.

Örneğin bir Ebola Hemorojik Ateşi (1976'dan beri bilinen bir hastalıktır. Kongo'da bir nehre hitaben Ebola ismi verilmiştir. Filavoviridae ailesinden bir RNA virüsüdür. 4 türünden insanlarda hastalık yapan üçü tanımlanmıstır, Ebola-Zaire, Ebola-Sudan, Ebola-Ivory Coast. Ebola, sporadik salginlar şeklinde görülür. Genelde medikal malzemelerle yayılır, muhtemelen tek vakalar da olmasına rağmen tanı konulmamaktadır, http://www.hssgm.gov.tr/?sf=bul_ebola\&nereden, 16 Temmuz 2006) ya da hemorojik humma (fever), (Flavivirüs cinsine ati bir arbovirüs olan sarı Humma virüsü. Sarl Humma, kentsel ve bazı kırsal alanlardaki enfekte edici Aedes Aegypty sineklerinin ya da Güney Amerika'daki ormanlardaki diğer sineklerin isırıklarıyla bulaşır. Bulaşma olayları 2500 metreye kadar olan yerleşim birimlerinde gözlenebilir. Insanlart enfekte etmektedir. Genellikle yerel vakalara ve küçük salginlara neden olur, http://www.hssgm.gov.tr/?sf=sey_karantina,16 Temmuz 2006) vakasında, bilinen hiçbir tedavi yolu yoktur. Özellikle, öldürücü biyolojik maddelerin grip gibi hızla ve kolaylıkla yayılan bir virüs ile genetik olarak birleştirilmesi sonucunda teröristler şimdiye kadar görülmemiş ölümcüllükte bir biyolojik zehrin yayılmasına neden olabilirler (http://www.emergency.com/cbwlesnl.htm, 26.02.2002).

Biyolojik silahların yapımında insanlardan, hayvanlardan ya da bitkilerden elde edilen patojeni mikro organizmalar kullanılmaktadır. $\mathrm{Bu}$ organizmalar bakteriler, virüsler, mantarlar ya da bunların türevleri olabilir. Bunlar doğada bulunabildiği gibi laboratuarda da üretilebilir. Her iki yolun amacı da enfeksiyon ya da zehirleme yoluyla yaralamak ya da öldürmektir. Kimyasal maddelerin aksine, çoğu biyolojik maddeler çoğalabilir ve insandan insana geçebilir. Biyolojik maddeler çok uzun süre ve en kötü şartlarda dahi varlıklarını koruyabilir. Yüksek derecede bulaşıcıdır ve büyük miktarlarda üretilebilmektedir (.http://www.bullatomsci.org, 9.02.2002).

Teröristler biyolojik bir maddeyi kitlesel zayiata neden olacak biçimde silahlandırmak ve yaymak için çeşitli teknik ve operasyonel zorluklardan geçmek zorundadır.

Biyolojik silahların kullanımının önündeki diğer bir engel, biyolojik silahları etkin biçimde yayma sorunudur. Biyolojik maddeler havaya yayıldıklarında çok hızlı bir şekilde dağılmaktadır. Dağılma süreci maddenin havaya karışma süreci içerisinde başlamakta ve saldırı açık havada düzenlendiği takdirde çevresel koşullar da maddenin etkinliğini azaltmaktadır. Güneş ışığı, sis, nem ve 1sı değişiklikleri patojenlerin yaşama ve çoğalma yeteneklerini düşürmektedir (http://www.cryptome.org/tpterr.htm,17.02.2002). Bu yüzden bir saldırı gerçekleştirebilmek için maddenin etkin biçimde yayılmış olması ve meteorolojik koşulların hesaba katılması gerekmektedir. Bütün bu zorluklara rağmen basit veya tamamlanmış bir yayma bile, özellikle saldırı bir kapalı alanda gerçekleştirilirse ölümlere ve yaralanmalara sebep olabilir.

Biyolojik silah kullanarak yapılacak terörist bir saldırı, 1998 yılında CIA tarafindan önlenmesi sonucunda gerçekleşmeden sona ermişti. Tıpkı Aum Shinriki gibi teröristlerin amacı tehlikeli bir biyolojik silah olan "antreks" kapsüllerini metro demiryollarına yerleştirmek ve tren hareketinden oluşan rüzgarla virüslerin metro istasyonlarını birleştiren 
aspiratör kanallarına sızarak her yere yayılmasını sağlamaktı. Teröristler elde ettikleri "antreks" kapsüllerini test etmek için laboratuar ararken CIA'ye gelen bir ihbar üzerine yakalanmıştı. Soruşturma sırasında teröristlerin ofislerinde bubonik vebaya yol açabilecek miktarda virüs ampulleriyle dolu kutular bulunmuştu. Teröristlerin Amerika'da oluşmuş ve Aydaho eyaletinde bürosu bulunan ETA'nın bir benzeri Katolik ve Protestanlar'dan oluşmuş milliyetçi terörist örgüte ait oldukları tespit edilmiştir. Bu terörist örgüt Amerika hükümetini Siyonistlik ile suçlamakta ve amacı bütün Yahudi ve diğer 1rklara karşı savaşmaktı. Yakalanan neo-faşist terörist grubun iki üyesi Larri Harris ve William Levit daha önceleri de New York metro altgeçidinde salgın bir hastalığın virüsünü yaydıktan sonra bütün şüphelerin Irak'a yönelmesini sağlamayı planlamıştı. Planları başarılı bir şekilde gerçekleşmiş olsaydı binlerce ölü ve yaralı dışında Yakındoğu'da yeni bir çatışmanın başlamasına sebep olabilirlerdi. CIA'in operasyonel hareket etmesi sonucunda iki terörist tutuklanmıştı. Fakat teröristlerin faaliyeti bunlarla sona ermedi ve 1997 yılında Harris bakteriyolojik virüsün nasıl elde edilebileceği hakkında bir belgesel çıardı. Bunun dışında kendi olanaklarıyla "Bakteriyolojik Savaş: Kuzey Amerika'nın En Büyük Tehlikesi" adlı bir kitap yayımlamıştı. Bunun dışında Harris'in internet aracılı̆̆ıyla kimyasal ve biyolojik silah üretimi ile ilgili çeşitli bilgileri yayınladığı belirlenmişti. Gazetelere verdiği mülakatlarda Amerika'nın biyolojik silah tehlikelerini ciddiye almayarak hata ettiğini birkaç kez vurgulamıştı. Radyoda verdiği bir başka mülakatında CIA için Irak'ta çalıştığını ve 1985-1990 yılları arasında Irak askerlerine biyolojik silah üretiminde yardım ettiğini ve bunu İran-Irak savaşı sırasında İran'a karşı bir silah olarak üretildiğini söylemişti (Kojushko, 2000, s.157).

Uluslararası alanda biyoterörizm tehdidine karşı etkili çok az araç bulunmaktadır. 1972 Biyolojik ve Toksin Silahlar Konvansiyonu biyolojik silahlar ile ilgili en önemli uluslararası anlaşmadır. Konvansiyon, bakteriyolojik maddelerin ve toksinlerin geliştirmesini, üretimini ve saklanmasını yasaklamıştır (Staten, 1999, s.8-11). Fakat Konvansiyonun biyoterörizm ile mücadele için, biyolojik silahlara karşı bir mücadelede fazla katkısı olmamıştır. Üstelik normlar terörizme odaklanmaktan ziyade devletlerden gelen tehditlere karşı yönelmiştir.

\section{KİTLE İMHA SİLAHLARININ TERÖRİSTLER TARAFINDAN KULLANIM TEHDİDININ ANALİZi}

Teröristlerin kitle imha silahı kullanarak yapabilecekleri saldırı tehdidinin parametreleri değerlendirilmelidir. Fakat bir değerlendirme yapabilmenin ardında yatan en önemli zorluk, bu tür saldırı örneklerinin Aum Shinriki örgütünün silahlanma programı ile sınırlı olmasıdır.

Motivasyon açısından değerlendirildiğinde KİS'e başvurarak kitle imhası yaratmaya çalışan en olası terörist gruplar kökten dinci örgütler, mistik dünya görüşleri olan mezhepler ya da radikal tek-sorun gruplarıdır. Materyal ve teknik sınırlamaları göz önüne alarak günümüz koşullarında teröristlerin az miktarda KİS maddeleri üretebileceği tahmin edilebilir. Bu yüzden KİS terörizminin en olası biçimi, küçük ölçekli saldırıların gerçekleşmesidir. Yakın gelecekte olası saldırıların besin kaynaklarının kirletilmesi gibi küçük ölçekli saldırılar ya da vasıfsız tehditler biçiminde gerçekleşebileceği de düşünülebilir (Turan, 2002, s. 104). 
KİS kullanılan bir terörist saldırının, neden olduğu zayiatla karşılaştırıldığında orantısız derecede büyük bir panik ve korkuya yol açma olasılığı çok yüksektir. Çünkü KİS saldırıları hiçbir uyarı olmadan, aniden ortaya çıkan, bulaşma ya da kirletme olasılığı taşıyan, halkın korkuları üzerine oynayan ve çok tanıdık olmayan bir tehdit biçimidir. Bu tipteki bir olayın sonrasında meydana gelebilecek panik ortamı, böyle bir saldırıya en hazırlıklı olan bir toplumda bile acil tepki kapasitelerini felce uğratabilir. Bu sonuçlar bile teröristlerin amaçlarına, daha kapsamlı silahların ya da kitle imhası içeren bir saldırının edeceği kadar hizmet edecektir. Bu nedenden dolayı teröristlerin kitle imhası gerçekleştirmeyi başarmak için kitle imha silahı kullanımın ötesinde, büyük bir kitle üzerinde geniş kapsamlı psikolojik etkiler yaratmak için hesaplanmış KİS silahları kullanmaları ihtimali göz ardi edilmemelidir.

\section{KONVANSIYONEL OLMAYAN KITLE IMMA SILAHI TEHDIDİ ANALIZi}

\section{Tehdidin Gerçekliği ve Ciddiyeti Tartışması}

Uluslararası alanda gerçekleşen değişimlere paralel olarak terörizmde de önemli değişimler meydana gelmeye başlamıştır. Şiddeti çok daha farklı amaç ve ilkeler için kullanan teröristler ortaya çıkmıştır. Özellikle dini motivasyon ile hareket eden terörist grupların saldırıları artmaya başlamıştır. Terörist saldırılar daha ölümcül hale gelmiştir; can kayıplarının oranı önemli miktarda artmıştır. Teröristler için kitle imhasının maksimizasyonu bir hedef haline gelmiştir. Brian Jenkins'e göre, terörist gruplar kendilerini siyasal ve sosyal sistemlerin dışına yerleştirdiklerinde ve Tanrı'nın vekilliğine sahip olduklarına içtenlikle inanarak, dini bir radikalizme yöneldiklerinde kitle imha silahlarını kullanmaktan alıkoyan ahlaki ve siyasi sınırlamaları terk etmektedirler (Vegar, 1998, s. 50-55).

Siyasi hedeflerinin nükleer silah kullanımında bir sınırlama oluşturduğu terörist gruplar, olanakları olduğu halde nükleer silah kullanmaktan kaçınırlar. Bu tür terörist grupların amacı karşıtlarının iktidarda olduğu ülkelere girmek ve iktidarı devralmaktır; bu yüzden de bu bölgeleri yok etmekten kaçınırlar. Onların hedefi faciaya yol açan nükleer saldırılarda bulunarak sayısız can kaybına neden olmak değil; amaçlarına ulaşmak için siyasi destek kazanmaktır.

Fakat bu El Kaide terörist örgütüne hitap eden bir durum değildir. El Kaide'nin amacı bir etnik, milliyetçi çatışma değil, küresel çapta bir savaştır; bu savaş için de nükleer silahların etkin sonuçları gerekmektedir. Taraftarlarının gözünde açılan savaşın meşruluğunu açıklamak için her yola başvuran terörist örgüt, savaş aracı olarak toplu şekilde sivil vatandaşları öldürmektedir (http://www.nti.org/CNWm,4.02.2005). Organizasyon planı olarak hedeflediği amaç, Amerika Birleşik Devletleri ve taraftarlarına yapılabilecek zayiatın maksimize edilmesidir. El Kaide örgütünün temsilcisi Suleyman Abu Gait, örgütün Müslümanların ölümüne sebep olan İsrail ve Amerika'ya karşı bir cevap olarak 4 milyon Amerikalı, onların içinden de 2 milyon çocuk öldürme hakkı olduğunu açıklamıştır (Suleyman Abu Gait'in yazıları eskiden www.alneda.com internet sayfasinda yayınlanmaktayd, daha sonra site birçok devletin baskısı altında kapatılmıştır. "Savaşların Gölgesinde" adlı makaleler dizisinde 11 Eylül'de gerçekleşen saldırllarını ve diğer kitle imha amaçlı saldırıların meşruluğunu savunmaktadır. Abu Gaid'in yazılarında El Kaide'nin kitle imhası gerçekleştirebilmek için nükleer silah 
kullanmaya hakkı olduğu yazılmaktadır. Daha detaylı bilgi için bkz, MEMRI: Middle East Research Institute Special Dispatch Series, Sayl 388, 2002, http://www.memri.org/sd.html, (2004), Usame Bin Laden ve El Kaide'nin en detayl analizi anonim bir kitapta belirtilmiştir; kitabın ismi: "Usame Bin Laden, Radikal İslam ve Amerika'nın Geleceği", (Through Our Enemies 'Eyes: Osama bin Laden, Radical Islam and the Future of America), Dalles, Brassey's, 2002, Ünlü terör uzmanı Bruce Hoffman, kitabı Bin Laden ve El Kaide'ye ithaf edilen çok başarılı bir kitap olarak, yazarın ise CIA'in 20 yıllık tecrübeli emektart olarak değerlendirmiştir. Bruce Hoffman' in "Al Qaeda Trends in Terrorism and Future Potentialities: An Assessment" adlı çalışması, RAND merkezinin "Yakın Doğu Siyasi Sorunlarl" ve Jeneva Siyaset ve Güvenlik Merkezinin düzenlediği "Afganistan ve Irak'tan sonra Yakın Doğu” adlı üçüncü konferansinda sunulmuştur, (Jeneva, İsveç 5, Mayıs, 2003, Aktaran, Bann, Wayer, http://www.nti.org/CNWm, 2.02. 2005).

El Kaide terör örgütünün taraftarları, kendilerinin Sovyetler Birliği'nin dağılmasına neden oldukları düşüncesindedir. Mücahitlerin başarılı bir şekilde Sovyet ordularını Afganistan'dan çıkarmaları sonucu SSCB dağılmıştır. Onların düşüncelerine göre, Amerika da SSCB'ye benzeyen bir "kağıt kaplandır" ve o da dağılabilir; ayrıca 11 Eylül saldırılarının ciddi bir şekilde Amerika'nın ekonomik zayiatına sebep olduğu vurgulanarak, örgüt lideri Bin Laden Amerikan ekonomik zararlarını yaklaşık bir trilyon dolar olarak değerlendirmiştir. Ayrıca, daha büyük kayıp ve zararlara yol açabilmek için birkaç saldırı daha gerçekleştirmeyi planladıklarını birkaç kez açıkça belirtmişlerdir. El Kaide'nin bugünkü amacı nükleer bir saldırı sonucunda Amerikan şehirlerinden birini yok etmektir. Bin Laden nükleer silah elde etmenin bir "dini görev" olduğunu açıklamıştır(http://more.abcnews.go.com/sections/world/DailyNews/trnscript_binladen1_9 90710.html, 23.02.2004). El Kaide'nin ele geçirilen mesajlarında bir başka hedefin Amerika'da yeni bir Hiroşima gerçekleştirmek olduğu bildirilmektedir (Risen, Engelberg, 2001).

El Kaide örgütü birçok kez nükleer silah veya nükleer silah yapımı için gerekli maddeleri elde etme girişiminde bulunmuştur (http://nti.org/e_research/cnwm/overview/report.asp,29.02.2004).

Örgütün Afganistan'daki eğitim kamplarında internetten alınmış nükleer bomba yapımı için gerekli şema ve bilgiler bulunmuştur. Bütün bunlar terörist grubun nükleer bir saldırı için zemin hazırlamakta olduğunu açıklamaktadır. Fakat nükleer saldırı hedefleyen tek terörist örgüt El Kaide değildir. Çeçen ayrılıkçıların birçok kez yaptığı açıklamalarından ve ele geçirilen dokümanlarından, nükleer silahlara karşı geniş çapta ilgileri olduğu anlaşılmaktadır. (El Kaide ve Çeçenler ilk bakışta ayrı amaç ve ilkeler peşinde olan gruplar olarak görünse de, aralarında sıkı bir bağlantı olduğu tespit edilmiştir. Bunun bir örneği, Çeçen teröristlerin El Kaide'nin Afganistan'daki eğitim kamplarında eğitilmesi, El Kaide örgüt üyelerinin Çeçen terör operasyonlarına katılmasıdır; diğer bir örnek ise Çeçen teröristlerin öldürülen liderlerinden Hattab'ın Arap olduğunun belirlenmiş olduğudur. Bu bağ, Amerikan hükümetini Çeçen teröristlerin nükleer silah elde etme konusunda El Kaide örgütüne yardım edebileceğinden büyük endişelere düşürmektedir. (Bann, Wayer http://www.nti.org/CNWm, Ocak 2005) 


\subsection{Kitle İmha Silahı Tehdidi İçin Gereken Kapasite ve Motivasyon Analizi}

Kitle imha silahlarını elde etmek ve kullanmak niyetinde olan bir terörist grubun belirli bir takım özelliklere sahip olması gerekmektedir. Grubun ideolojisi, amaçları, demografik özellikleri, mali kaynakları, liderlik yapısı ve özellikle yüksek bir teknolojiye sahip olma gibi unsurların hepsi bir kitle imha silahı kullanarak yapılacak saldırının gerçeğe dönüşebilmesi için bir arada olması şart koşulan zorunluluklardandır. Bunun ötesinde, kitle imha silahları kendileri için de ciddi tehlikeler taşımaktadır. Bu silahların etkilerinin ne olacağının açık olarak tahmin edebilmesi mümkün değildir ve bu tip saldırılar beraberinde çok ciddi bir misilleme tehdidini taşımaktadır. Ancak, son yıllarda yukarıda belirtildiği gibi artan fanatizm ve geleneksel sınırlamalarda yaşanan erozyon, teröristler açısından pragmatik hesapların ortadan kalkması ve daha önce kitle imha silahlarının kullanımının önünde duran engellerin önemsenmemesi yolunda bir eğilimi beraberinde getirmektedir.

(http://www.news.findlaw.com/cnn/docs/crs/wpnsmssdst120899.pdf,17.2002).

Teknolojik gelişmeler ve kitle imha silahı yapımı konusundaki bilgilerin yaygınlaşması tek başına kitle terörünün ortaya çıkmasına neden olan unsurlar arasında değildir. Terörist grupların bu eğilimlerinin arkasında yatan ve kitle imha silahlarının kullanılmasına neden olan motivasyonlar farklılık gösterebilmektedir. Başta teröristlerin mümkün olduğu kadar fazla sayıda insanı öldürme hedefleri söz konusu olabilir. Bu açıdan kitle imha silahları tek bir vuruş ile binlerce kişiyi öldürme potansiyeline sahiptir. $\mathrm{Bu}$ tip silahlar teröristlerin önde gelen hedeflerine ulaşmak için mükemmel bir araç sağlamaktadır. Teröristlerin kitle imha silahlarına başvurmalarının bir diğer nedeni, bir amatör teröristin bu tür silah kullanarak profesyonel terörist gruplar kadar ölümcül ve yıkıcı eylemler gerçekleştirebilme olanağıdır. Terörist saldırıların artan ölümcüllük oranı, teröristlerin operasyonlarında çok daha profesyonel ve daha az siyasi olduklarının, eski tarzdaki ahlaki sınırlamalar ile bağlı olmadıklarının göstergesidir (Turan, 2002, s. 68).

\section{KITLE IMHA SİLAHLARIN DEVLETLER TARAFINDAN SAĞLANMASI}

Teröristlerin kitle imha silahı elde etme ve kullanma konusunda incelenmesi gereken bir diğer nokta, Batı politikası ile açık çatışma içerisinde olan devletlerin, teröristlerin bu tür silahları elde etmeleri konusunda oynayabileceği roldür. Teröristlerin sponsor devletlerden birçok konuda destek aldığı açıkça bellidir. Fakat nükleer silahlar gibi hassas konularda terörizmin yanında yer alıp almayacakları araştırılması gereken ciddi bir konudur. Terörist grupların devlet destekli kitle imha silahı programlarına sahip olması bu yolda aşılması gereken birçok engelin arkada bırakılması anlamına gelecektir. Bu tür olanaklara sahip oldukları takdirde bu gruplar için nükleer, radyolojik, kimyasal ve biyolojik maddeleri kitle imhası için uygun ve etkili silahlara dönüştürme sorunu büyük miktarda azalacaktır. Terörizmi faal olarak destekleyen devletlerin gizlice kitle imha silahlarının kapasitelerini geliştirme girişimlerinde bulundukları bilinmektedir. Bu ülkelerin, kendi bölgesel etkinliklerini genişletmek için ya da egemen uluslararası sistemin hâkim güç yapısına karşı koymanın bir aracı olarak bir kitle imha saldırısını destekleme olasılığı endişelendiren bir 
gelişmedir (Turan, 2002, s.70). Uluslararası alanda kabul edilmiş normlara uymaktan kaçınan Sudan, Kuzey Kore gibi devletlerin arasında özellikle İran, daha önce teröristlere verdiği yardımlarla büyük endişeler uyandırmaktadır. Çünkü bu devletlerden biri teröristlerin kitle imha saldırısını jeopolitik çerçevesinde değerlendirdiği takdirde, bir kitle imha eyleminin gerçeğe dönüşmesi mümkün olabilecektir. Fakat bu olasılık ne kadar ciddi ve göz önüne alınması gereken bir tehlike olarak görünse de devletler tarafından gönüllü bir şekilde terörist gruplarına nükleer silah verilmesi mümkün görünmemektedir. Saldırıya uğrayan devlet veya uluslararası toplum tarafından nükleer silahlı saldırıda bulunma tehlikesi, nükleer silahlara sahip terörist örgütlerin üzerindeki kontrol kaybı korkusu ve nükleer silahların başka bir tarafa verilmesinin istenmemesi gibi faktörler devletlerin bu tür sponsorluklarda bulunmasinı engellemektedir (http://usinfo.state.gov/journals/itps/0305/ijpr/cameron.htm, 4.03.2005) .

Ayrıca eğer bir terörist grubun kitle imha saldırısını böyle bir devletin sağladığ 1 silahlar ile gerçekleştirdiği ortaya çıkarsa bu devlete karşı uluslararası bir askeri müdahale söz konusu olabilecektir. Son olarak kitle imha kapasitesine en çok sahip olmak isteyen terörist grupların önceden tahmin edilemeyecek hareket tarzından dolayı, terörist örgütlere destek sağlayan bir devlet hiçbir zaman terörist örgütün bu silahları kendisine karşı kullanabilme ihtimalini göz ardı edemez (http://www.mipt.org/bremerreport.html, (15.10.2001).

Buna rağmen Şubat 2005'te Kuzey Kore'nin nükleer silahlara sahip olduğuna dair yaptığı açıklamalar, bu konularda tedirginlik yaratmaktadır. Özellikle de Kuzey Kore'nin daha önce diğer devletlere füze satışında bulunduğu göze alınırsa bu tedirginlik daha iyi anlaşılabilecektir. Fakat devletlerin bu tür desteklerde bulunma ihtimalinden daha çok devlet bilim yönetiminde veya askeri yönetimde bulunan şahısların maddi ve ideolojik nedenlerden dolayı terörist örgütlere nükleer silah veya silah üretimi için gerekli tesisat, kaynak ve bilgi vermek konusunda yardım edebilecekleri ihtimali daha yüksektir (http://usinfo.state.gov/journals/itps/0305/ijpr/cameron.htm, 2.03.2005).

Brian Jenkins bir devletin çizgiyi aşıp bir düşmana karşı kitle imha silahlarını kullanmadan ya da bu tür silahları terörist gruplara vermeden niçin kaçınacağını şu şekilde açıklamaktadır: "Devletin bir adresi vardır ve böyle bir harekete dünyadan gelecek karşıllk çok güçlü olacaktır. Diğer taraftan bu devletlerin bu silahları teröristlere verme ihtimali de çok düşüktür; çünkü devletler, bu gruplara büyük operasyonlar için güvenmemektedir. Devlet terörizmindeki eğilim, büyük operasyonlar gerektiğinde devletlerin kendi insan kaynaklarını kullanması yönünde olmaktadır (Vegar, 1998, s.50-55). Bu konuda ulaşılabilecek sonuç, haydut devletlerin maliyet-fayda oranı gözeterek hareket edecekleridir. Nükleer terörizmi desteklemenin maliyeti, faydalarından daha ağır bastı̆̆ 1 sürece devletin terörizm desteği yukarıda belirtilen yardımlardan daha fazla olmayacaktır (http://www.cns.miis.edu/pubs/reports, 20.02.2002).

Birçok uzman tarafindan teröristlerin ancak devlet desteği sonucunda nükleer silah elde edebilmelerinin mümkün olduğu düşünülmektedir. Nitekim BM'nin Irak'taki temsilcisi Richard Butler'ın bu konudaki düşünceleri şu şekildedir: "Bir terörist grubun herhangi bir nükleer silah elde edebilmesi ancak bir devlet desteği sonucunda mümkün olabilir. $\mathrm{Bu}$ tür silahlar teröristlere bir devlet ya da kanun ile barışı olmayan 
vatandaşlarından biri tarafından verilebilir." (Butler, 2001, s.89) Aynı şekilde, ABD Başkanı G. Bush yaptığı bir konuşma sırasında "haydut devletlerin" kimyasal, biyolojik ve nükleer silahların bir kaynăg 1 olabileceğini vurgulamıştır. $\mathrm{Bu}$ inanç siyasetin yürürlüğünü de belirlemektedir. Eğer teröristlerin nükleer silah elde etme tehlikesi düşman devletlerden geliyorsa bunun çözümü bu tür devletler ile ilgilenmek ve teröristlere silah desteğini kesmesi için baskı uygulamaktır. Bu strateji, ABD Başkanı Bush'un da terörizme karşı mücadele programında yer almaktadır. Aynı strateji Amerika'nın Irak'a girmesine sebep olmuştur. Fakat bu tür stratejiler geliştirilirken göz ardı edilen önemli bir nokta vardır; bu da bütün dünya üzerinde dağılan nükleer silahların ve nükleer silah yapımı için gerekli maddelerin korunması konusudur. (http://www.whitehouse.gov/news/releases/2001/12/20011211-6html, (29.03.2004

Harvard Üniversitesi nükleer silah uzmanları M. Bann ve E. Wayer'in yaptığ 1 ve ortaya çıkardığı çalışmalar, bu tür düşüncelerin asılsız olduğunu ve terörist örgütlerin bir devlet desteği olmaksızın nükleer silah elde edebileceklerini göstermektedir (http://www.nti.org/CNWm, 4.02. 2005). Bu tez, daha önce de uzmanların birçok çalışmasında doğrulandığg gibi bir terörist grup, devletin desteği olmadan basit de olsa nükleer bir bomba yapabilir. Fakat etkili bir nükleer bomba yapımı için gerekli maddeleri elde edebilmeleri tehlikesi hala ciddiyetini korumaktadır. Batı düşmanı olarak belirlenen devletler, teröristlerin nükleer silah elde etme konusunda destekleme ihtimalini azaltsalar da teröristlerin başka yollarla nükleer silah elde etmelerini engelleyemezler. Teröristlerin söz konusu olanaklara ulaşmalarını engelleyebilmek için maddelerin ciddi bir şekilde korunması ve maddelerin korunması konusunda uluslararası işbirliğinin sağlanması gerekmektedir.

\section{SONUÇ}

Küresel terörizm kavramının ortaya çıkmasıyla daha çok şiddet içeren, kitle imha silahlarının kullanıldığı, geniş bir kitlenin yok edilmesinin hedeflendiği tehdit çok boyutlu olarak tartışılmış ve bu tehdide karşı çözüm yolları aranmıştır. 20 Mart 1995 'te Aum Shinriko (Adalet Kurulu/Yüce Gerçek) Tarikatı'nın Tokyo metrosuna yönelik saldırılarında sinir gazı sarin kullanmış olması teröristlerin bu tür silahlar kullanarak saldırıya geçebileceğinin bir örneğiydi. Kitle imha silahlarının çok sayıda insana zarar verebilmesi ve etkisinin medya aracılığıla dünya çapında yayılması teröristlere çok büyük bir avantaj sağlamaktadır.

Kitle imha silahlarının elde edilebilmesi zor olmasına rağmen bazı devletlerin yeterli güvelik tedbirlerini almaması teröristlerin nükleer silah elde etmesini kolaylaştırmaktadır. Eski Sovyetler Birliği'nden nükleer materyal ve bilimsel teknik uzmanlık sızıntısı bu konuda endişelere yol açmakta ve teröristlerin nükleer silah elde etme olasılığını arttıran bir unsur olarak değerlendirilmektedir. Endişe yaratan bir diğer nokta da nükleer maddelerin çalınmasıdır. Bilimsel amaçla kurulan nükleer santraller kolaylıkla teröristlerin saldırılarına maruz kaldığ gibi çevrenin radyolojik kirlenmesine de neden olabilir. El Kaide terör örgütü gibi diğer radikal dini örgütlerin birçok kez nükleer silah yapma teşebbüsünde bulunduğu bilinmektedir. İnternet aracılığıyla bu tür silahların yapılması için gereken bütün bilgilere ulaşmak mümkün olduğu gibi basit patlayıcıların yapılması için yüksek teknolojilere veya herhangi bir deneyime de ihtiyaç 
duyulmamaktadır. Onların başarısızlığı şimdilik gerçekleşebilecek büyük bir faciayı önlemektedir, fakat terörist grup üyelerinde çoğu zaman iyi eğitim almış, çeşitli uzmanlıklara sahip insanların bulunduğu göze alınırsa nükleer terörizm tehdidi ciddi bir şekilde dünyayı tehdit altında tutmaktadır.

Nükleer terörizmi önlemek için devletlerin ilk olarak yapması gereken, nükleer silahları ve nükleer silah yapımı için kullanılan maddeleri özenli bir şekilde korumaktır. Daha sonra teröristlerin kolaylıkla saldırılarına maruz kalabilecek nükleer santrallerin korunması gerekmektedir. Bu konuda özelikle devletlerin devreye girmesi ve nükleer santrallerin korunması için özel koruma sistemi hazırlaması olası bir saldırı sonucu çıkabilecek faciaları önlemesi açısından önemlidir. Bununla birlikte nükleer silahların sayımının yapılması, kesin rakamların belirlenmesi ve sürekli kontrol edilmesi gerekmektedir.

\section{KAYNAKÇA}

BOGDANOV,V, A Pass to Warheads Found on a Terrorist, Rossiyskaya Gazeta, 1.10. 2002

BELOUS,V.S, Ugroza Zahvata Yadernogo Orujiya, Nezavisimoye Obozreniye gazetesi, 08 .10. 2004

BELOUS,V.S, Yadernıy Terrorizm: Popıtki Uje B1li, http://nvo.ng.ru/concepts/2004-10-08/4_terrorism.html, (8 .10.2004)

BANN,M, ENTON,W, Securing the Bomb : An Agenda for Action, http://www.nti.org/CNWm, (04.02. 2005)

BOAZ,G, , Non-Conventional Terrorism: Chemical, Nuclear, Biological, The İnternational Policy İnstitute For Counter-Terrorism, http://www.ict.org.il, (25 .04.1998)

BOWMAN,S, BAREL H, Weapons of Mass Destruction : The Terrorist Threat, ARS Report for Congress, 8 December, 1999, http://www.news.findlaw.com/cnn/docs/crs/wpnsmswsdst120899.pdf, (17 .02. 2002)

ELLİSON, G, Yadernıy Terrorizm; Realnost Ugrozı dlya Rossiyi, http://www.globalaffairs.ru/articles/0/3069.html, (18.10.2004) 
CLARK,L, Emergency Response to Chemical and Biological Terrorist İncidents", Emergency Response and Research İnstitute, , http://www.emergency.com/cbwlesnl.htm, (26 .02. 2002)

GILMOUR,J, , Meade, Catherine, Westfall, “Critical Assembly: A Technical History of Los Alamos During the Oppenheimer Years 19431945”, Cambridge University Press, 1993, s. 367-370

JENKINS, B.M, (2003), İnternational Terrorism: The Other World War, The New Global Terrorism, s. 20-23

KAMERON,G, Yaderniy Terrorizm, Orujiye Na Prodaju ili Vorovstvo?, http://usinfo.state.gov/journals/itps/0305/ijpr/cameron.htm, (02.03. 2005)

LEVENTHAL, L, YOHAN ,A, Preventing Nuclear Terrorism, Lexington Books, 1987, http://www.nci.org/k-m/makeab.htm, (29 .03. 2004)

STOBER, D, No Experience Necessary, Bulletin of the Atomic Scientists, http://www.thebulletin.org/past_issues/059_002htm, (29 Nisan 2004)

SAPRIKIN,V, Yadernaya Ugroza so Storonı Terroristov Realna, http://www.zerkalo-nedeli.com/nn/show/371/33091/, (7. 01. 2001)

OLBRAYT,D, O’NIL, K, Yadernıy Terrorizm, Nevoobrazımıy Koşmar, http://npc.sarov.ru/digest/42001/section5.html, (19 .09. 2001)

PARACHINİ,J, Combatting Terrorism: Assessing the Threat", Congressional Testimony, http://www.cns.miis.edu/pubs/reports, (20 .02. 2002)

PATE,J, ACKERMAN,G, MC CLOUD,K, WMD Terrorism Chronology : İncidents İnvolving Sub-National Actors and Chemical, Biological, Radiological or Nuclear Materials, Center for Nonproliferation Studies, http://cns.miis.edu/pubs, (17 .02.2002) 
THORTON, T. P, (1964), Terror as a Weapon of Political Agitations, İnternal War, s. 73

TURAN, G, (2002), 21.Y.Y Uluslararası Terörizmin Değisşen yüzü. Yayınlanmamış Yüksek Lisans Tezi, s 48, 69

VEGAR,J, Terrorism's New breed : Are Today's Terrorists More Likely to Use Chemical and Biological Weapons?", Bulletin of Atomic Sciences, Say1 2, Cilt 54, 1998, s.50-55 